UDC $329.63+316.346$

DOI: https://doi.org/10.21564/2663-5704.50.235050

Huk Luidmyla Ivanivna, $\mathrm{PhD}$ in Pedagogy, Associate Professor, Associate Professor of Foreign Language Department,

Lviv Polytechnic National University, Ukraine

e-mail: Luidmila.I.Huk@lpnu.ua

ORCID ID: 0000-0002-7216-8844

Grabchak Marta Oleksandrivna, student,

Lviv Polytechnic National University, Ukraine

e-mail:mgrabchak27@gmail.com

ORCID ID: 0000-0003-3895-3408

\title{
YOUTH PARTIES IN EU COUNTRIES
}

The article attempts to conduct a comparative analysis of youth parties in the EU. Investigate theoretical approaches to understanding the concept of "political party» - as well as to highlight the main features and characteristics of youth parties.

Keywords: theoretical approaches, youth parties, innovations, democratic, sociopolitical, restrictions.

Problem setting. Today, young people play significantly important role in the modern world. Thanks to innovations, new technologies, laws, it is young people who show themselves as progressive, democratic personalities. Now, young people have virtually none restrictions on the realization of their dreams and themselves. Nowadays they play a very big role play in socio-political life [1, p. 5]. Because it is the youth who see the obsolete principles of political life, they can compare what was once and what is now. Also, now, there are many youth political (not only organizations) but also parties, because modern young people are ready to change everything from old politics to current and create a new one. Best of all, the citizens of each state, where there are youth parties, support this younger generation. Methods used in the work: the historical method was used in the study themselves youth political parties, namely: the year of foundation, how and why created; the logical method, it was most manifested in comparison with the political one party and youth political party; and the method was used inductions and deductions, which allowed us to draw conclusions in this work; structural and functional: the structure and features were determined youth political and political party.

Recent research and publication analysis. Among the scholars who have considered the European youth movement are the following: H. Gere, A. Daifal, 
L. Landau, G. Sitaraman, R. Warren, K. Hanson. To study the state of youth policy in Europe, special institutions have been set up to conduct constant monitoring and analysis of this issue. One of the most influential among them is the European Center for Knowledge on Youth Policy. In Ukraine, a similar structure is the State Institute for Family and Youth Policy, which constantly transmits data to the European Center for Knowledge on Youth Policy, and employees of both structures regularly hold joint events. Among the Ukrainian researchers of youth problems and the development of youth movements are M. Golovaty, T. Kovalev, O. Kornievsky, N. Latov, Y. Latov, G. Lux, V. Pavlovsky, I. Seleznev, O. Tarasov.

Paper objectives. The goal of the article is to conduct a comparative analysis of youth parties in the EU. Also investigate theoretical approaches to understanding the concept of "political party" as well as to highlight the main features and characteristics of youth parties.

Paper main body. At the present stage of EU development, the political process within the Union receives new forms of implementation that require legal regulation. Yes, it can be argued that it is being formed and functioning at the EU level the EU's unique supranational party system, which is a system of relations rivalry and cooperation between political parties (national and supranational) at the supranational level, as well as the system of relations between parties and supranational institutions of power [2, p. 25].

Interestingly, the UN notes that with the growing number of young people on planet, it becomes the most powerful factor in shaping society. By according to the UN Commission on International Humanitarian Affairs, by the end of the XXI century. People under the age of 30 will make up almost $60 \%$ of the world's population, and up to 25 years - about $50 \%$. Therefore, we must understand that the population is such age categories are getting bigger and bigger, so the world is progressing with every day [3].

Today we see that it is young people who take an active part participation in various protests, actions. For example, "Umbrella Revolution", "Revolution on Granite", "Revolution of Dignity", young students came out against government decisions [4, p. 610]. But over time, with history, it is because of these protests, because of these indignations, distrust to power, youth parties begin to form as students begin to understand that one of the easiest ways to defend their own interests in politics - through political institutions, one of which is a political party. Also, we can say that youth policy begins with organizations in which young people learn to communicate, to defend their own civic position, articulate their own interests. As a result activity increases the level of political consciousness and the young person becomes conscious an active person who understands his place and role in the political system. In fact, through the organization leadership qualities, team decisions, there are various discussions, and we think that's why a lot of young 
people start creating political parties, because that's when they really are analyze a solution, you can find a solution to one or another problems, and even then on a psychological level, they understand that for in order to change something you need to start with yourself.

First of all, we want to start with political parties. In general, what is it political party, what are its features and compare how it differs from public organization [5, p. 18]. A political party is a legally registered association of people that has common goal and wants to achieve it, the goal, by gaining political power. Signs of a political party: desire for power; the desire for support from the people; development of a political program; the presence of an organized structure; activity in election campaigns [6, p. 503-505]. Structure of a political party: as with any organization, team, association or project, it should to be a leader who manages everything, who is the highest class, the one who provides practically everything [7, p. 543-546]. A political party is no exception, so it is the first in its structure and the highest participant is the leader who plays a leading role: accept the important decision, concentrates in its hands all the information about the activities of the parties, and manipulates the consciousness and behavior of the party masses. The next class structure and much more important is the bureaucracy that communicates between higher and lower party structures and carries out the orders of the leadership. Sometimes the bureaucracy can be separated from other parts of the party and even take the party leadership into their own hands, as in any company and the political party has active and passive members of this organization $[8$, p. 829]. So, it's active those who participate in the full implementation of the political program they seek problems of solving this or that mistake. These people can also practice disseminating information of this party, to advertise it. Look for others who will help them in their work, also these are the people most often involved in local elections, practically made up of a party, these people can be different specialists in different fields (economists, lawyers, medical professionals, cultural figures). And the opposing party members have passive members. If so, say in short, they seem to be a member of the party, but do not take part in its program. Volunteers are a very important and last link in a political party. Which help to do the smallest but important work? They are the ones who help active members and they advertise all events, hand out flyers for greater party recognition. So now that we understand what a political party is, we can [9]. We want to start moving to youth political parties (youth parties) from youth organizations, as the youth party is a kind of youth organizations.

A youth organization is a united group of people aged 14-35 their purpose is to exercise and protect their rights and freedoms, as well as satisfaction economic, cultural, social, economic, global, environmental, including political interests. Youth organizations usually provide youth: scholarship grants, and also do various 
youth, usually cultural, political, environmental exchanges. All funds and support are sponsored by almost the EU. The youth organization, created voluntarily, decides independently problems that operate in forms that do not contradict the law.

Youth policy is a purposeful activity through which the problems of the youth are solved and all the conditions necessary for it are created personality development of a young person. Thanks, this activity is achieved understanding between youth and society and government. Youth policy covers all spheres of youth life, includes all issues related to the formation and education of youth, covers all processes of socialization, the whole set of ideas about the place and role of youth in society and their implementation. Youth policy is a set of actions of all state and public institutions, but each of its subjects, social the institution carries it out differently according to its needs and opportunities taking into account local conditions [10, p. 12].

The subjects of youth policy are the state, government agencies (which practically implement this policy), political parties, public organizations and associations, trade unions, social institutions (education, culture), individual citizens and, of course, young people themselves [11, p. 20]. A youth political party is a number of young people under the age of 29 years within the EU, it can act as an organization or as a movement that aims at social political interests, defends the rights of citizens, is created voluntarily, and desires new changes in the state, does not contradict the law, decides all political issues of their country, participates in various meetings, discussions, for political purpose may be different [8, p. 827].

Usually, a party arises just when a certain group is aware the need for political organization in order to participate in government decisions and issues, as well as for their own interests and young people, aware of their own interests, creates political structures [12, p. 267]. If so, we compare youth NGOs and youth political parties, we will see that the parties are more eager to exercise power powers, influence political processes and aim to obtain authorities, and organizations put pressure on the authorities in the process of adoption and implementation of political decisions in order to satisfy the interests of its members. The goal of the youth political party is that they want to have their own political power, as well as ordinary political parties, and exercise their interests. Also, they set up advisory bodies as a tool to put pressure on power. And if we talk about the target audience of political parties, then we are we can say that their interest group is the entire population of the country, from 18 years and older. Political parties have the spread of advertising (television, media, social networks, newspapers, magazines, etc.) much more than youth. They are more focused on the whole nation.

Youth, mostly use methods of advertising social networks, because for them it is more peculiar. And because of this, they are seen by fewer older generations, because not all are interested in the Internet, and usually watch the news on televi- 
sion or also read newspapers [13, p. 20-27]. Youth parties want more development from the students themselves, young people, so that young people have more opportunities to discover themselves, take an active part in elections, in solving the problems of the state, to be aware of allbmistakes and were politically aware. So, summarizing all the above, we can conclude that youth political parties and political parties differ from each other: purpose, structure, characteristics and target audience. Although they have a common goal, purpose and the desire for power. Today in the European Union is almost general discourses of the party, which are formally only youth wings, movements or classical organizations are perceived as full-fledged youth. Another one one factor gives them the right to be called parties that they have their own separate names, as well as the right to vote [14, p. 50]. In fact, there are many such movements or wings in the European Union. But, the EU also has one youth party, which used to be just a movement and now is already officially German sources call it youth EU party.

Volt Europe - (Volt Europe) - pro-European, European federalist largest political youth party. Volt wants to spend policies at local, national and European levels. The Progress Youth Party is the Norwegian youth wing political party of Progress. In fact, it is considered freer than the party of Progress itself. The wing has active divisions in counties and over 50 municipalities of Norway. Libertarian, direct, democratic - youth rights populist, Flemish political conservative liberal, libertarian party in Belgium. When the party won five seats in the House and one seat in the Senate and eight seats in the 2009 Flanders election, she surprised all commentators. Young Conservatives is a youth political organization founded in the Czech Republic, it is also a youth wing of the Civic Democratic Party, it is center-right, conservative and economically liberal. Ogra Shinn Fein (known as the Republican Youth) is a youth wing of the Irish political party Shinn Fein. The European Free Youth Alliance is a youth wing, founded in 2000 by the European Free Political Alliance European party. It is a pan-European youth organization which includes members of political organizations, they protect and promote: linguistic and cultural national diversity of Europe [9]. Young European Socialists is an organization of the Party of Europeans socialists; it is an association of youth organizations in Europe and of the European Union. Place of organization - Brussels.

Conclusions of the research. Having carried out a comprehensive study of the issue of youth political parties of the EU and carrying out their comparative analysis, we can come to the following conclusions: a political party is a legally registered association of people that has a common goal and wants to achieve it, the goal by gaining political power; signs of a political party: desire for power; desire for support from the outside the people; political program development; the presence of an organized structure; activity in election campaigns; a youth political party is 
a certain number of young people up to 29 years within the EU (according to Eurostat source Being young in Europe today), it can act as an organization or as a goal-oriented movement socio-political interests, defends the rights of citizens, is created voluntarily and wants new changes in the state, does not contradict the law, resolves all political issues of his country, participates in various meetings, discussions, for political purposes, may be different. Signs of youth political parties: the pursuit of common interests (their interests, usually completely different from a political party); members and leaders of this party there are young people under the age of 29 . The main feature is that these parties usually participate in the activities of international organizations, such as the United Nations, where a special department of youth policy was created; the structure of the youth political party is almost no different from the structure of a regular political party, but there are small nuances in that depends on the country in which it exists and is registered. For example in Germany the Youth Union consists of land and district associations. That is, the structure of the youth political party may change; party youth policy of political associations provides for two main directions: ideological training of young party members; attracting new ones representatives of the younger generation to the organization by conducting socio-political, cultural, historical, educational and other events; there are 3 types of youth parties: a group of common ideological political purpose. The main goal is to protect national interests and gaining state power; a youth organization created for the purpose political expression and protection of the interests of youth, its representation in state institutions; paramilitary formations are an association that operates for pressure on the current political and power structures. Today in the European Union almost in general discourses of the party, which are formally only youth wings, movements or classical organizations are perceived as full-fledged youth. Actually, there are many such movements or wings in the European Union. In this paper we the following were studied: Volt Europa - pro-European, European federalist largest political youth party. Volt wants to spend policies at local, national and European levels; Youth the Progress Party is the youth wing of the Norwegian political party Progress; Libertarian, direct, democratic - populist youth rights, Flemish political conservative - liberal, libertarian party in Belgium; Young Conservatives is a youth political organization, founded in the Czech Republic, is also a youth wing of the civic democratic party, it is center-right, conservative and economically liberal; Ogra Shinn Fein (known as the Republican Youth) is the youth wing of the Irish political party Shinn Fein; European Free Alliance of Youth - is a youth wing, founded in 2000 by European Free Alliance of European Political Party; Young people European Socialists is an organization of the Party of European Socialists, it is association of youth organizations in Europe and the European Union; we analyzed each of the 7 youth political parties for the following criteria: date of foundation, founder / first head, levels 
implementation of activities, place of activity, ideology, governing body, supporters and members, future intentions, support for EU reforms, and funding activities. Note that each of the considered political organizations is unique in its activities and views on ideology and directions activities. However, we can say that each of them is designed to develop youth party organizations both in individual European countries and throughout Europe in general.

\section{REFERENCES}

1. Huntington, S. (2011). The Clash of Civilizations and the Remaking of World Order. New York: Simon \& Schuster.

2. Domkina, V., Donets, A., \& Hladchenko, T. (Eds.). (2006). Molodizhna polityka Yevropeiskoho Soiuzu: perspektyvy ta shliakhy zaprovadzhennia v Ukraini [Youth Policy of the European Union: Prospects for the Future in Ukraine]. Donetsk: Donetskyi Molodizhnyi Debatnyi Tsentr [in Ukrainian].

3. Savranskyi, R. S. (2017). Poniattia ta sutnist prypartiinykh molodizhnykh orhanizatsii [Concept and essence of youth wing of political parties]. Derzhavne upravlinnia: udoskonalennia ta rozvytok - Public Administration: Improvement and Development, (4). Retrieved from http://nbuv.gov.ua/UJRN/Duur_2017_4_17 [in Ukrainian].

4. Trebin, M. P. (Ed.). (2015). Politolohichnyi entsyklopedychnyi slovnyk [Political science encyclopedic dictionary]. Herasina, L. M., Pohribna, V. L., Polishchuk, I. O., et al. (Comps.). Kharkiv: Pravo [in Ukrainian].

5. Savchuk, L. S. (2018). Molodizhnyi parlamentaryzm yak instutytsiina forma uchasti molodi u protsesi pryiniattia rishen: dosvid Yevropeiskoho Soiuzu ta Ukrainy [Youth parliamentarism as an institutional form of youth participation in the decision-making process: the experience of the European Union and Ukraine]. Derzhava ta rehiony. Seriia: Derzhavne upravlinnia - State and Regions. Series: Public Administration, 62(2), 17-24 [in Ukrainian].

6. Denysenko, V. M., Sorba, O. M., Uhryn, L. Ya., et al. (2014). Politolohiia. Khoma, N. M. (Ed.). Lviv: Novyi Svit - 2000 [in Ukrainian].

7. Levenets, Yu. (Ed.). (2011). Politychna entsyklopediia [Political Encyclopedia]. Kyiv: Parlamentske vydavnytstvo [in Ukrainian].

8. Kitanova, M. (2020). Youth Political Participation in the EU: Evidence from a CrossNational Analysis. Journal of Youth Studies, 23(7), 819-836. DOI: https://orcid.org/ 10.1080/13676261.2019.1636951.

9. von Kummert, T. (2018). Jugendpartei "Volt" will Europa umkrempeln. Wirtschafts Woche. https://www.wiwo.de/politik/deutschland/zwoelf-sterne-bewegung-jugendpartei-volt-will-europa-umkrempeln/22665188.html.

10. Kremen, V. H. (Ed.). (2016). Natsionalna dopovid pro stan i perspektyvy rozvytku osvity v Ukraini [National Report About the State and Prospects Development of Education in Ukraine]. Kyiv: Pedahohichna dumka [in Ukrainian].

11. Pashkov, A. P., Baranovska, A. S., \& Teliukova, Yu. M. (2017). Analiz zahroz natsionalnoi bezpeky Ukrainy ta peredovyi dosvid shchodo yikh rozv'iazannia [Analysis 
of National Security Threats of Ukraine and Best Experience About Their Solution]. Bezpeka zhyttediialnosti - Life Safety, (1), 20-25 [in Ukrainian].

12. Trebin, M. P., Herasina, L. M., Polishchuk, I. O., et al. (2013). Politolohiia [Political science]. Trebin, M. P. (Ed.). Kharkiv: Pravo [in Ukrainian].

13. Berezovska-Chmil, O. B., Chernyshova, T. O., Kuchyn, S. P., et al. (2021). Spetsyfika rozvytku suchasnoho sotsialno-humanitarnoho seredovyshcha [The specifics of the development of the modern social and humanitarian environment]. Kharkiv: SH NTM "Novyi kurs" [in Ukrainian].

14. Platon, Aristotel' (2002). Pajdejja: Voshozhdenie k doblesti [Paideia: Rise to Valor]. Kornetov, G. B. (Ed.). Moskva: Izd-vo URAO [in Russian].

Гук Людмила Іванівна, кандидат педагогічних наук, доцент, доцент кафедри іноземних мов, Національний університет «Львівська політехніка», Україна

Грабцак Марта Олександрівна, студентка,

Національний університет «Львівська політехніка», Україна

\section{МОЛОДІЖНІ ПАРТІї В КРАЇНАХ СС}

Постановка проблеми. На сьогоднішній день молодь відіграє надзвичайно важливу роль у сучасному світі. Завдяки інноваціям, новим технологіям, законам саме молоді люди показують себе як прогресивні, демократичні особистості. Зараз молоді люди не мають практично жодних обмежень щодо реалізачії своїх мрій та себе особисто. У наш час дуже велику роль вони відіграють у суспільно-політичному житті. Бо саме молодь бачить застарілі засади політичного життя, може порівнювати те, щчо було колись, із тим, що є тепер. Також нині існує безліч молодіжних політичних організацій і партій, бо сучасні молоді люди готові змінювати все і створювати нову політику. Найкраще те, що громадяни кожної держави, де є молодіжні партії, підтримують ие підростаюче покоління.

Аналіз публікацій. Серед науковців, які розглядали питання європейського молодіжного руху, слід назвати Х. Гиру, А. Дайфала, Л. Ландау, Г. Сітараман, Р. Уоррен, К. Хансон. Для дослідження стану молодіжної політики в Європі створено спеціальні інституиії, які проводять постійний моніторинг та аналізують ијю проблематику. Однією з найвпливовіших серед них є Свропейський центр знань з молодіжної політики. В Украӥні аналогічною структурою є Державний інститут сімейної та молодіжної політики, який постійно передає дані до Європейського центру знань із молодіжної політики, а прачівники обох структур регулярно проводять спільні заходи. Серед украӥнських дослідників проблем молоді та розвитку молодіжних рухів треба назвати М. Головатого, Т. Ковалеву, О. Корнієвського, Н. Латову, Ю. Латова, Г. Лукса, В. Павловського, І. Селезнева, О. Тарасова та ін. 
Формулювання цілей. Провести порівняльний аналіз молодіжних партій в СС. Дослідити теоретичні підходи до розуміння поняття «політична партія», а також виокремити основні ознаки й особливості молодіжних партій. Розглянути основні молодіжні політичні партії в Свропейському Союзі.

Виклад основного матеріалу. На сучасному етапі розвитку ЄС політичний процес усередині Союзу отримує нові форми втілення, які потребують правової регламентації. Так, можна стверджувати, що на рівні СС формується і функціонує унікальна наднаціональна партійна система СС, яка є системою відносин суперництва та співробітництва між політичними партіями (нащіональними та наднаціональними) на наднаціональному рівні, а також система відносин між партіями та наднаціональними інститутами влади. Цікавий факт: ООН зазначає, щзо зі зростанням чисельності молоді на планеті вона стає наймогутнішим фактором у формуванні суспільства. За даними Комісії з міжнародних гуманітарних питань ООН, до кіния XXI cm. люди віком до 30 років становитимуть майже 60\% населення земної кулі, а до 25 років - близько 50\%. Отже, ми повинні розуміти, щзо населення таких вікових категорій все збільшується $і$ збільшується, тому світ прогресує з кожним днем. Методи, які було використано в роботі: історичний метод був використаний при дослідженні молодіжних політичних партій, а саме: рік заснування, як та чому створилася; логічний метод найбільше проявлявся у порівнянні політичної партії та молодіжної політичної партії; також застосовано методи індукиії та дедукиії, які дозволили зробити висновки у даній роботі; структурнофункиіональним методом було визначено структуру та ознаки молодіжної політичної та політичної партіі).

На сьогодні ми бачимо, що саме молоді люди беруть активну участь у різних протестах, акиіях. Наприклад, «Революиія парасольок», "Революиія на граниті», «Револючія гідності», молоді студенти вийили проти рімень влади. Та з часом, з історією, саме через ці протести, через чі обурення, недовіру до влади, починають утворюватися молодіжні партії, оскільки студенти починають розуміти, щуо один із найпростіших шляхів обстояти власні інтереси в політиці - через політичні інститути, одним з яких і є політична партія. Ознаки політичної партії: прагнення до влади; прагнення підтримки з боку народу; розробка політичної програми; наявність організованої структури; активність у виборчих кампаніях. Також можна сказати, щзо молодіжна політика починається з організачій, у яких молодь вчиться комунікувати, аргументовано обстоювати власну громадянську позицію, артикулювати власні інтереси. Унаслідок такої активності зростає рівень політичної свідомості, і молода особа стає свідомою активною особистістю, яка розуміє своє місие і роль у політичній системі. Насправді через організацію формуються лідерські якості, командні рімення, відбуваються різні обговорення, і я думаю, що саме через иче багато молодих людей починають створювати політичні партії, бо саме тодi, коли вони реально аналізують те чи інше рімення, можна найти вирішення тієі чи іншої проблеми, і вже саме тоді на психологічному рівні вони розуміють, що для того, аби щось змінити, потрібно почати з себе. 
Висновки. Здійснивши комплексне дослідження питання щодо молодіжних політичних партій країн ЄС та їх порівняльний аналіз, можемо дійти таких висновків: політична партія - це юридично зареєстроване об'єднання людей, яке має спільну мету і хоче ї̈ досягти шляхом отримання політичної влади. Ознаки політичної партії: прагнення до влади; прагнення підтримки з боку народу; розробка політичної програми; наявність організованої структури; активність у виборчих кампаніях. Зауважимо, що кожна із розглянутих політичних організацій є унікальною в свой діяльності та поглядах щьодо ідеології і напрямків діяльності. Проте можемо стверджувати, що кожна із них покликана розвивати молодіжні партійні організації як в окремій європейській краӥні, так і в Європі загалом.

Ключові слова: теоретичні підходи, молодіжні партії, винаходи, демократичний, соиіально-політичний, обмеження.

Гук Людмила Ивановна, кандидат педагогических наук, доцент, доцент кафедры иностранных языков, Национальный университет «Львовская политехника», Украина

Грабчак Марта Александровна, студентка, Национальный университет «Львовская политехника», Украина

\section{МОЛОДЕЖНЫЕ ПАРТИИ В СТРАНАХ ЕС}

На сегодняшний день молодежь играет исключительно важную роль в современном мире. Благодаря инновациям, новым технологиям, законам именно молодые люди показывают себя как прогрессивные, демократические личности. Сейчас молодые люди не имеют практически никаких ограничений относительно реализаичи своих желаний и себя. В наше время очень большую роль они играют в общественно-политической жизни. Ведь именно молодежь видит устаревшие основы политической жизни, может сравнивать то, что было когда-то, с тем, что есть сейчас. Также сегодня существует множество молодежных политических организаиий и партий, потому что современные молодые люди готовы менять все и создавать новую политику. Лучше всего то, что граждане любого государства, где есть молодежные партии, поддерживают это подрастающее поколение.

Ключевые слова: теоретические подходы, молодежные партии, изобретения, демократический, сочиально-политический, ограничения. 